\title{
Factors affecting the labour productivity of brickwork and analyzing them using RII method
}

\author{
Mahesh S. Singh ${ }^{1^{*}}$,Tejaswini D. N. ${ }^{2}$, Raju Narwade ${ }^{3}$ and Karthik Nagarajan ${ }^{3}$ \\ Research Scholar, Pillai HOC College of Engineering and Technology, Rasayani, Maharashtra, India ${ }^{1}$ \\ Professor, Pillai HOC College of Engineering and Technology, Rasayani, Maharashtra, India ${ }^{2}$ \\ Associate Professor, Pillai HOC College of Engineering and Technology, Rasayani, Maharashtra, India ${ }^{3}$
}

Received: 16-March-2019; Revised: 26-May-2019; Accepted: 29-May-2019

(C)2019 Mahesh S. Singh et al. This is an open access article distributed under the Creative Commons Attribution (CC BY) License, which permits unrestricted use, distribution, and reproduction in any medium, provided the original work is properly cited.

\begin{abstract}
Productivity is one of the major problems which affects the duration of the project. There are many factors which affect productivity like climate, type of material, supervision etc. In the current research, the factors affecting the labour productivity of brickwork activity are identified through a literature survey and discussions with industry experts. Total 27 factors were identified and a survey questionnaire was prepared which was distributed among the site engineers to rate factors on a Likert scale from 1 to 5 . To make the questionnaire simple the factors were distributed into 3 main groups such as (i) management, (ii) project specification and (iii) human and labour. The questionnaire was distributed among 130 under construction sites and data was obtained. The data analysis was done through the relative importance index and ranking of factors was done which showed results as (i) training, (ii) quality required, (iii) experience, (iv) safety training, (v) proper scheduling and (vi) over time. These top 6 factors were responsible for affecting the labour productivity of brickwork the most.
\end{abstract}

\section{Keywords}

Brickwork, Labour productivity, Relative importance index, Construction industry, Management.

\section{Introduction}

In the Indian construction sector, labour productivity is considered as one of the tedious problems which affect the total duration of the project [1]. As per Jergeas and McTague [2], the cost of labour contributes around $40 \%$ to $50 \%$ of the total cost of the project. Productivity is one of the major concerns which occurs during a discussion about the construction industry [3]. In 1950, the Organization for European Economic Cooperation (OEEC) introduced a formal definition of productivity as a quotient obtained by dividing output by one of the production factors. The United State Department of Commerce defined productivity as "dollars of output per person-hour of labour input" [4]. Peles [5] interpreted productivity as the task finished by labours, whereas Handa and Adballa [6] stated productivity as the ratio of outputs of goods and/or work with the input of resources such as material, labour, wages etc.

\footnotetext{
*Author for correspondence
}

The American Association of Cost Engineers defined productivity as a as a comparison between the efficiency of a labour with the predefined base or norm [7] while Arditi and Mochtar [8] referred the productivity as the ratio between total outputs to the total input in dollars. Kenley [9] expressed productivity as how much is the output produced by providing input.

It is the imperious aspect in the construction industry as it allows cost savings and effective utilization of resources. It is considered to be the most important concern in both developed and developing countries [10]. As per the literature survey, it can be stated that productivity is defined as the ratio of output produced with the input provided for the given work to be accomplished.

There are many factors which affect labour productivity directly or indirectly, for example, age, experience, climate, inspection delay etc. It is necessary to identify those factors and find measures to avoid them so that productivity can be increased. 
Many studies have been carried out on labour productivity in different countries where researchers considered many factors in their research like 50 factors [11] in Malaysia, 45 factors [12] in Israel, 83 factors [13] in the United States of America, 45 factors [14] in Kuwait, 27 factors [15] in Egypt, 52 factors [16] in Yemen. Similarly, Rahman et al. [17] in Pakistan identified 33 factors affecting the labour productivity. It was observed in the literature survey that many researchers have used the method of the relative importance index (RII) to identify the top factors affecting productivity. The RII method requires factors to be rated on a Likert scale (3 points, 4 points, 5 points or 7 points Likert Scale). In current research 5 points, the Likert scale is used. It consists of nos. 1 to 5 and each no. indicates an opinion. In the current research 1 indicates not important, 2 indicates less important and so on. Through the literature survey, it is determined that many of the researchers have adopted RII method for determination of the top factors affecting productivity like M. R. Hafez et al. [15] has highest RII value of 91.1 and the least value as 59.8. Whereas Adnan Enshassi et al. [12] identified top 8 factors with highest RII value 84.21 and lowest as 54.74 likewise Jarkas and Bitar [14] kept the highest value to be 81.67 and lowest as 52.87 for top 10 factors. Similarly, Hafez et al [15] had a range of RII value as 87.74 to be the highest RII value and 76.73 to the lowest value for selecting the top 10 factors. Gerges, M. et al. [18] kept the RII range for selecting the top 10 factors as 85.79 to 81.58. Similarly, Porntepkasemsant et al. [19] has a range of the top 16 factors as 71.3 to 54.9. Many of the previous researches showed the effect of factors on total productivity of the overall construction of a structure.
Through identification of factors affecting the different operations in construction like flooring, concreting, tiling, formwork etc. [20-24]. It will be very easy to increase the overall productivity. The current study tends to identify the factors affecting labour productivity only for the operation of brickwork. It is one of the most crucial and important activities that is considered in the industry. Following are objectives of current research.

- Identification of factors affecting the labour productivity of brickwork.

- Categorizing the factors into main groups.

- Calculating the relative importance index of each factor.

- Ranking them on the basis of RII value.

\section{Methodology}

The main aim of the current study is to identify the factors and prioritize them according to their RII calculation. The methodology is divided into four major steps such as (i) identification of factors, (ii) classification of factors into categories, (iii) preparation of questionnaire and (iv) analysis of data and ranking of the factors. To accomplish the above aim intensive literature review is being done and 22 factors were identified also additional 5 factors like (i) over man (quantity of labour more than the required), (ii) education, (iii) health, (iv) physique and (v) quality required were also considered in case of brickwork labour productivity. These 5 factors were added after interacting with more than 15 engineers, 10 contractors and 20 labours. All the 27 factors which are considered for research shown in Table 1.

Table 1 Factors affecting labour productivity

$\begin{array}{ll}\text { Training } & \text { Rad and Kim [23] } \\ \text { Inspection Delay } & \text { Olomolaiye et al. [20] } \\ \text { Design Rectification } & \text { Zakeri et al. [21] } \\ \text { Crew Size } & \text { Olomolaiye et al. [20] } \\ \text { Proper Scheduling } & \text { Soekiman et al. [22] } \\ \text { Language Barrier } & \text { El-Gohary and Aziz [24] } \\ \text { Supervision } & \text { Soekiman et al. [22] } \\ \text { Habits } & \text { Rad and Kim [23] } \\ \text { Labour Strikes } & \text { Soekiman, et al. [22] } \\ \text { Absenteeism } & \text { Olomolaiye et al. [20] } \\ \text { Bonus/Incentives } & \text { El-Gohary and Aziz [24] } \\ \text { Safety Training } & \text { Dai et al. [13] } \\ \text { Government Policies } & \text { Abdul et al. [11] } \\ \text { Experience } & \text { Enshassi et al. [12] }\end{array}$




\begin{tabular}{ll}
\hline Overtime/Fatigue & Enshassi et al. [12] \\
Alcoholism & Enshassi et al. [12] \\
Material Delay & Abdul et al. [11] \\
Types of Material & El-Gohary and Aziz [24] \\
Site Environment & Zakeri et al. [21] \\
Climate & Zakeri et al. [21] \\
Equipment Availability & Jarkas et al. [14] \\
Age & Enshassi et al. [12] \\
Over manning & Discussion with industrial experts \\
Education & Discussion with industrial experts \\
Health & Discussion with industrial experts \\
Physique & Discussion with industrial experts \\
Quality required & Discussion with industrial experts \\
\hline
\end{tabular}

\subsection{Classification of factors}

The previous research on labour productivity showed that the researcher classified all the identified factors into main groups. The identification of the factors and its classification vary from country to country and activity to activity. Alaghbari et al. [16] in Yemen classified identified factors into four groups (i) human/labour factors, (ii) management factors (iii) technical and technological factors and (iv) external factors whereas Jarkas et al. [14] in Kuwait divided factors into 4 main groups (i) management, (ii) technological, (iii) human/labour and (iv) external. This group of factors will help in finding out which group is affecting productivity more. Therefore, in the current study 27 factors were classified into three major groups (i) management, (ii) project specification and (iii) human and labour. The classification helps in identifying which groups is more responsible for affecting the productivity of brickwork. Figure 1 gives a detail classification of factors into three major groups.

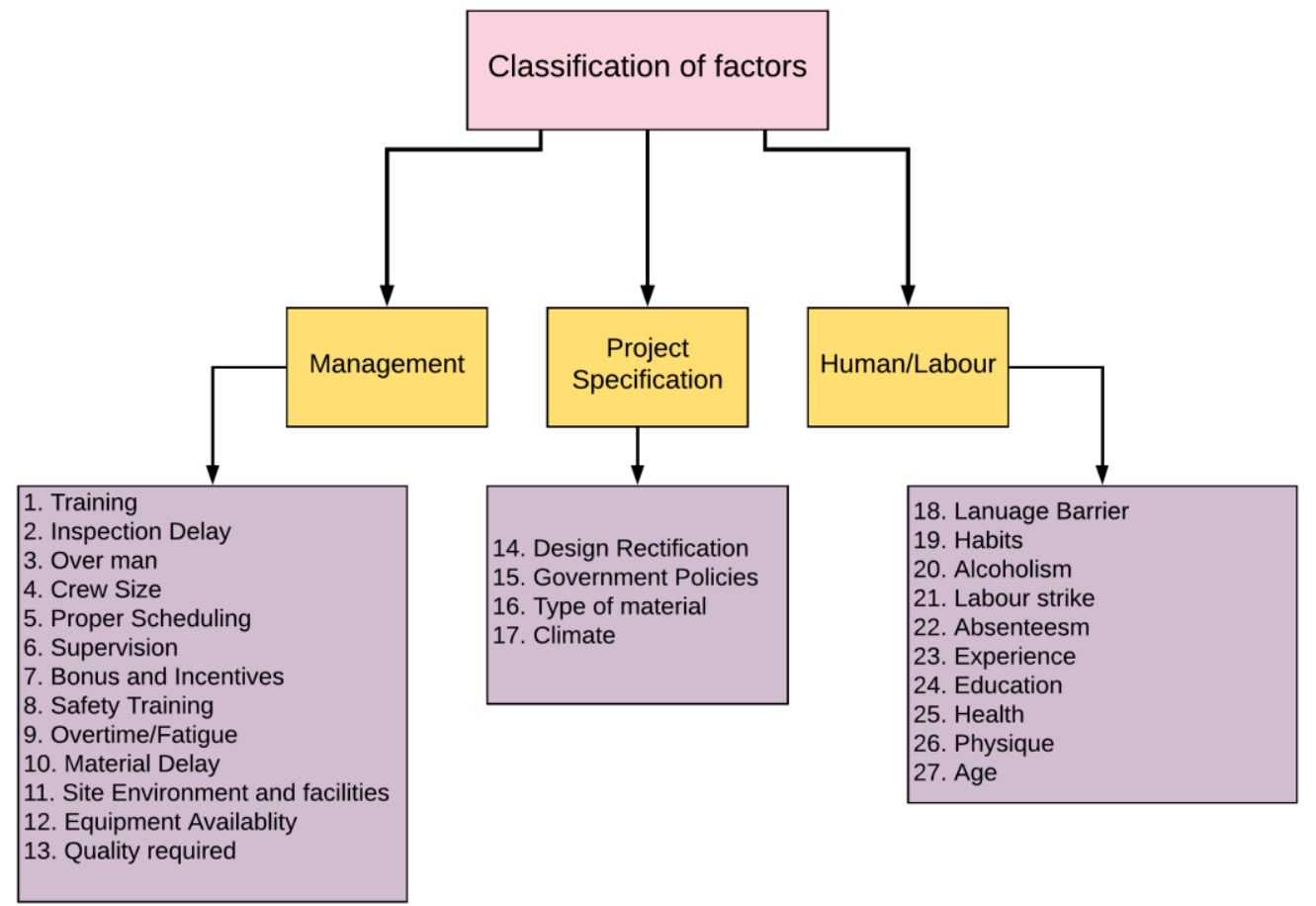

Figure 1 Classification of factors 


\subsection{Preparation of questionnaire}

The current research aims at identifying the factors affecting the labour operation for data were collected from 118 under construction sites. For the collection of this data, a questionnaire was prepared and distributed among them. It consisted of various entities like the name of the engineer, name of the site etc. These 27 factors were lined across which there was 5 points Likert scale and an individual has to choose only one option for it. Figure 2 shows the sample of the questionnaire.

\begin{tabular}{|c|c|c|c|c|c|c|c|}
\hline \multicolumn{8}{|c|}{ Name of the site: } \\
\hline \multirow{2}{*}{\multicolumn{8}{|c|}{$\begin{array}{l}\text { Name of the site engineer: } \\
\text { Location: }\end{array}$}} \\
\hline & & & & & & & \\
\hline \multicolumn{8}{|c|}{ Type of construction } \\
\hline \multirow{2}{*}{\multicolumn{8}{|c|}{$\begin{array}{l}\text { Following are some of the factors which are being selected so please give your responge on } \\
\text { the scale of } 1 \text { to } 5 \text { by } \\
\text { NOTE: Only one option can be selected in each category. }\end{array}$}} \\
\hline & & & & & & & \\
\hline \multirow{3}{*}{ Sr. } & \multirow{3}{*}{ Group } & \multirow{3}{*}{$\begin{array}{c}\text { Factors affecting } \\
\text { labour } \\
\text { productivity }\end{array}$} & \multicolumn{5}{|c|}{ Rating } \\
\hline & & & $\begin{array}{c}\text { Very } \\
\text { Important }\end{array}$ & Important & $\begin{array}{l}\text { Somerihat } \\
\text { Important }\end{array}$ & $\begin{array}{c}\text { Less } \\
\text { Impartant }\end{array}$ & $\begin{array}{l}\text { Nat } \\
\text { Important }\end{array}$ \\
\hline & & & 5 & 4 & $\overline{3}$ & 2 & 1 \\
\hline 1 & \multirow{13}{*}{ Management } & Training & & & & & \\
\hline 2 & & Inspection Delay & & & & & \\
\hline 3 & & Over man & & & & & \\
\hline 4 & & Crew Size & & & & & \\
\hline 5 & & $\begin{array}{l}\text { Proper } \\
\text { Scheduling }\end{array}$ & & & & & \\
\hline 6 & & Supervision & & & & & \\
\hline 7 & & Bonus/Incentives & & & & & \\
\hline 8 & & $\begin{array}{l}\text { Safety Training } \\
\text { to acoid } \\
\text { Accidents }\end{array}$ & & & & & \\
\hline 9 & & Oxertime & & & & & \\
\hline 10 & & Masterial Delay & & & & & \\
\hline 11 & & $\begin{array}{c}\text { Site } \\
\text { Enxiraument }\end{array}$ & & & & & \\
\hline 12 & & $\begin{array}{l}\text { Equipment } \\
\text { Arailability }\end{array}$ & & & & & \\
\hline 13 & & Quality Required & & & & & \\
\hline 14 & \multirow{2}{*}{$\begin{array}{l}\text { Project } \\
\text { Specification }\end{array}$} & $\begin{array}{c}\text { Design } \\
\text { Specification }\end{array}$ & & & & & \\
\hline 15 & & $\begin{array}{c}\text { Goxermment } \\
\text { Policies }\end{array}$ & & & & & \\
\hline
\end{tabular}

Figure 2 Sample questionnaire

\subsection{Data Analysis}

The RII method was applied to rank the factors affecting productivity as the data received from the respondent's analysis was conducted for the calculation of RII value. The RII method is a determined approach for calculating employee satisfaction $[25,26]$ hence it is very suitable to use it for current research. It helps in the decision making of an individual and easy for selecting the factors responsible for it. Following formula is being used to analyze the collected data [14].
Relative Importance Index $(\%)=$ $\frac{1 n_{1}+2 n_{2}+3 n_{3}+4 n_{4}+5 n_{5}}{5\left(n_{1}+n_{2}+n_{3}+n_{4}+n_{5}\right)} \times 100$

Where, $n_{1}, n_{2}, n_{3}, n_{4}$ and $n_{5}$ are the no. of respondents selected: (1) not important (2) less important (3) somewhat important (4) important and (5) very important respectively. For all the data analysis Microsoft Office Excel was used. 


\section{Results}

The main aim of the current study was to identify the top 6 factors affecting the labour productivity of brickwork. The relative importance index was calculated for each factor. The 27 factors were divided into three categories 13 factors in the management group, 4 factors in project specification group and 10 factors in human and labour group. There are two methods used for giving ranks to all the factors viz. (i) ranking according to the group and (ii) overall ranking of all factors. The hard copies of the questionnaire were distributed among the engineers of the 130 under construction sites in Dombivli region. Only 118 respondents were received which is $90.76 \%$ of the total distribution.

\subsection{Ranking according to the groups}

In this method of ranking the factors was done according to the RII value in their individual group and comparison was done with the rank of a factor in the overall ranking.

3.1.1.Management group

This group consists of 13 factors as shown in Figure 1. The relative importance indices of the factors classified under the management group are shown in Figure 3. The factor "training" has the maximum RII value $76.44 \%$, which indicates that if the workers are given proper training of brickwork the productivity may increase. This factor was ranked $1^{\text {st }}$ in the overall ranking of 27 factors as shown in Table 2. Others factors like quality required, site environment, safety training, proper scheduling, overtime, crew size, supervision, equipment availability and inspection delay have the RII value in descending order. In overall ranking 5 factors from the management group were observed in top 10 hence it can be concluded that this group plays a vital role in labour productivity.

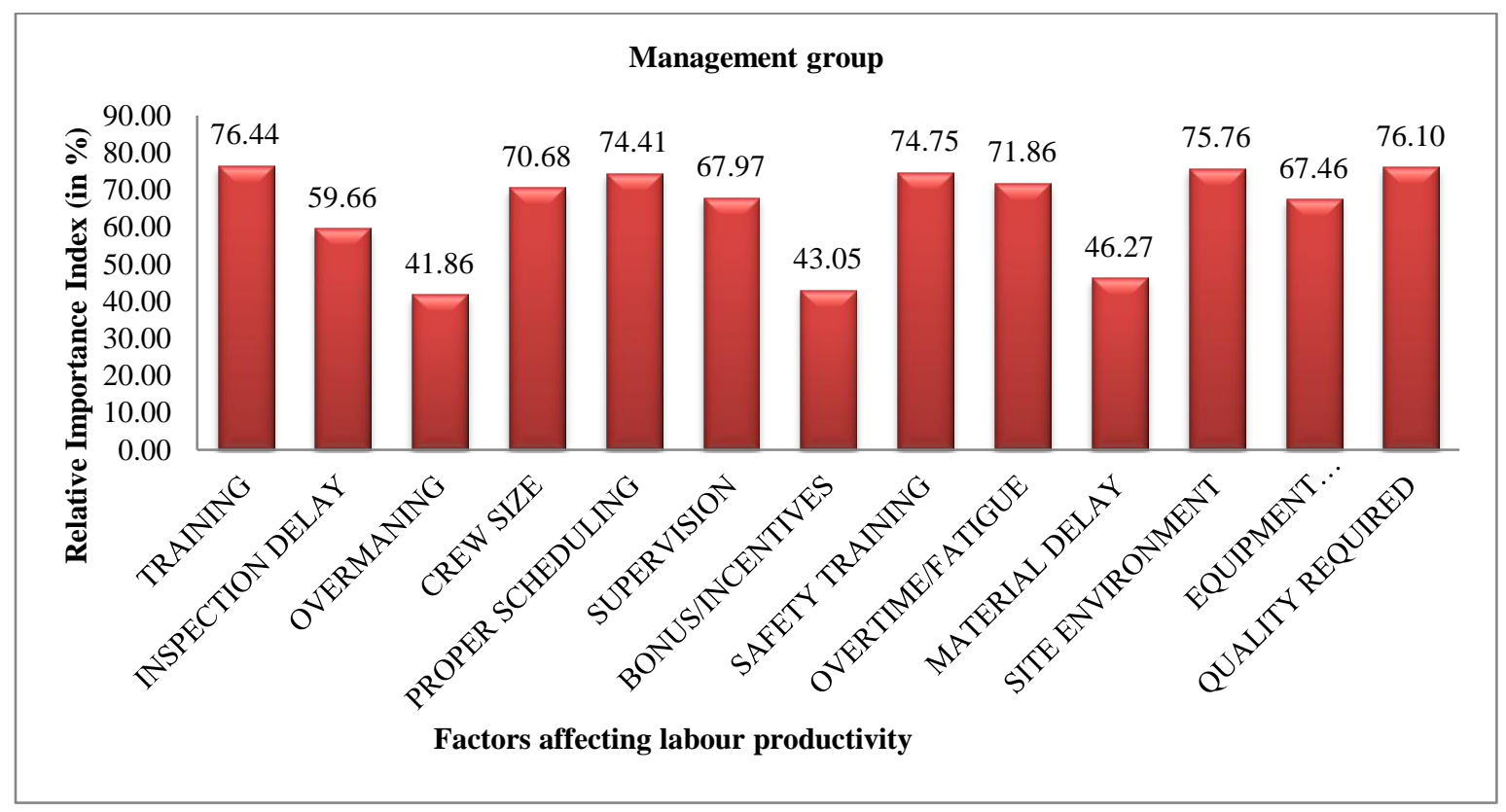

Figure 3 RII values of factors

3.1.2. Project specification group

This consists of 4 factors as shown in Figure 1. The top factor to an RII value of 71.18 was the "type of material". It was ranked $7^{\text {th }}$ in the overall ranking as shown in Table 2. Type of material generally decreases the productivity of brickwork if the brick is of any other material other than the conventional brick. The density of the material also plays a major role in which construction of the brickwork. Figure 4 shows the RII value of the factors of this group. 


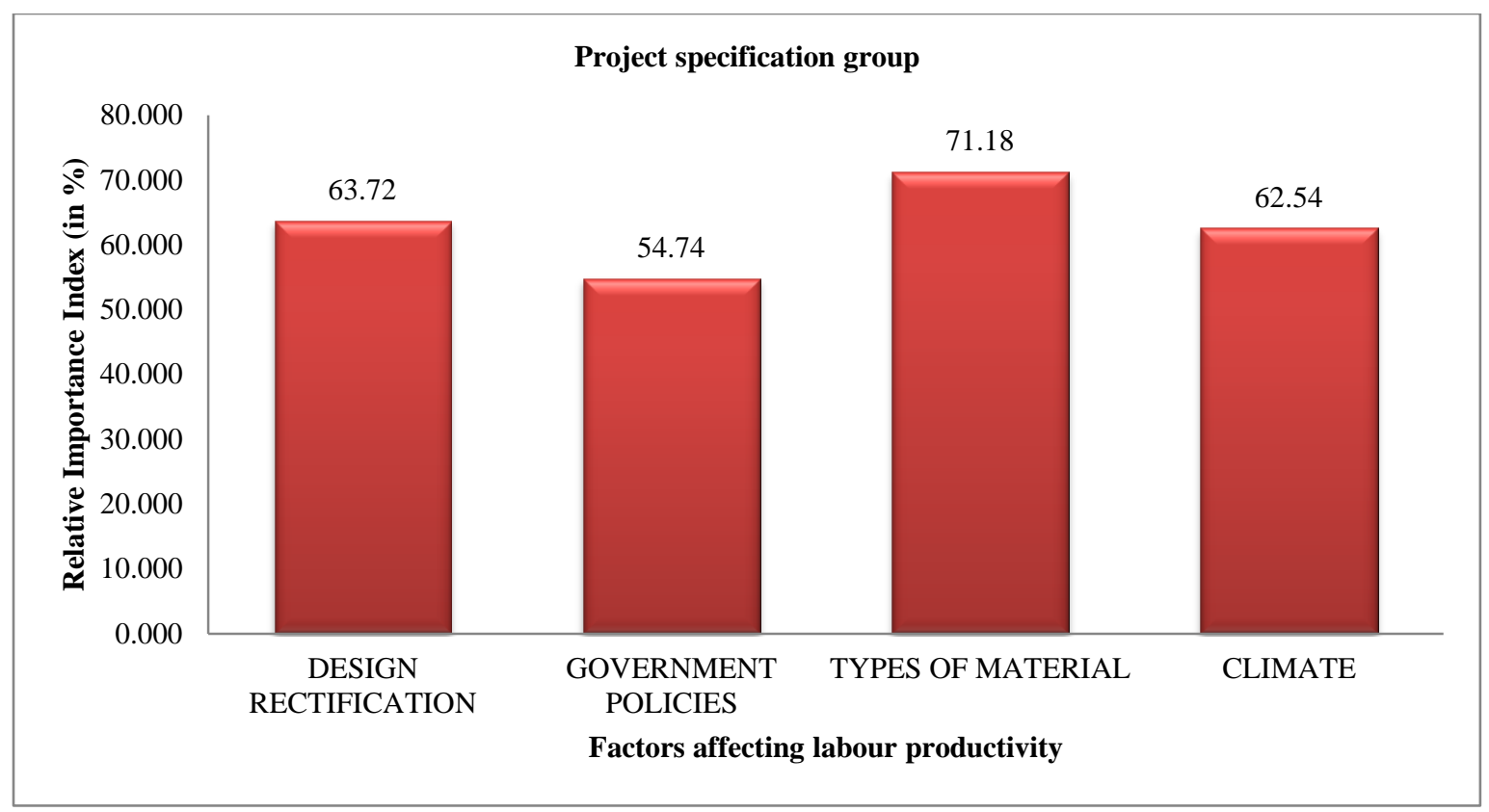

Figure 4 RII values of the factors

\subsubsection{Human and labour group}

This group consists of 10 factors as shown in Figure 1. This group mainly consists of factors related to labours personal details like their experience, age, health, physique etc. As per the result obtained the obtained data from different sites when RII was calculated of the factors it was observed that "experience" top of the group with $75.76 \%$, which was seen to be at 3rd rank in the overall ranking as shown in Table 2. In an activity like the brickwork experience of labour plays a major role in increasing productivity. Figure 5 shows the RII of all the factors included in this group.

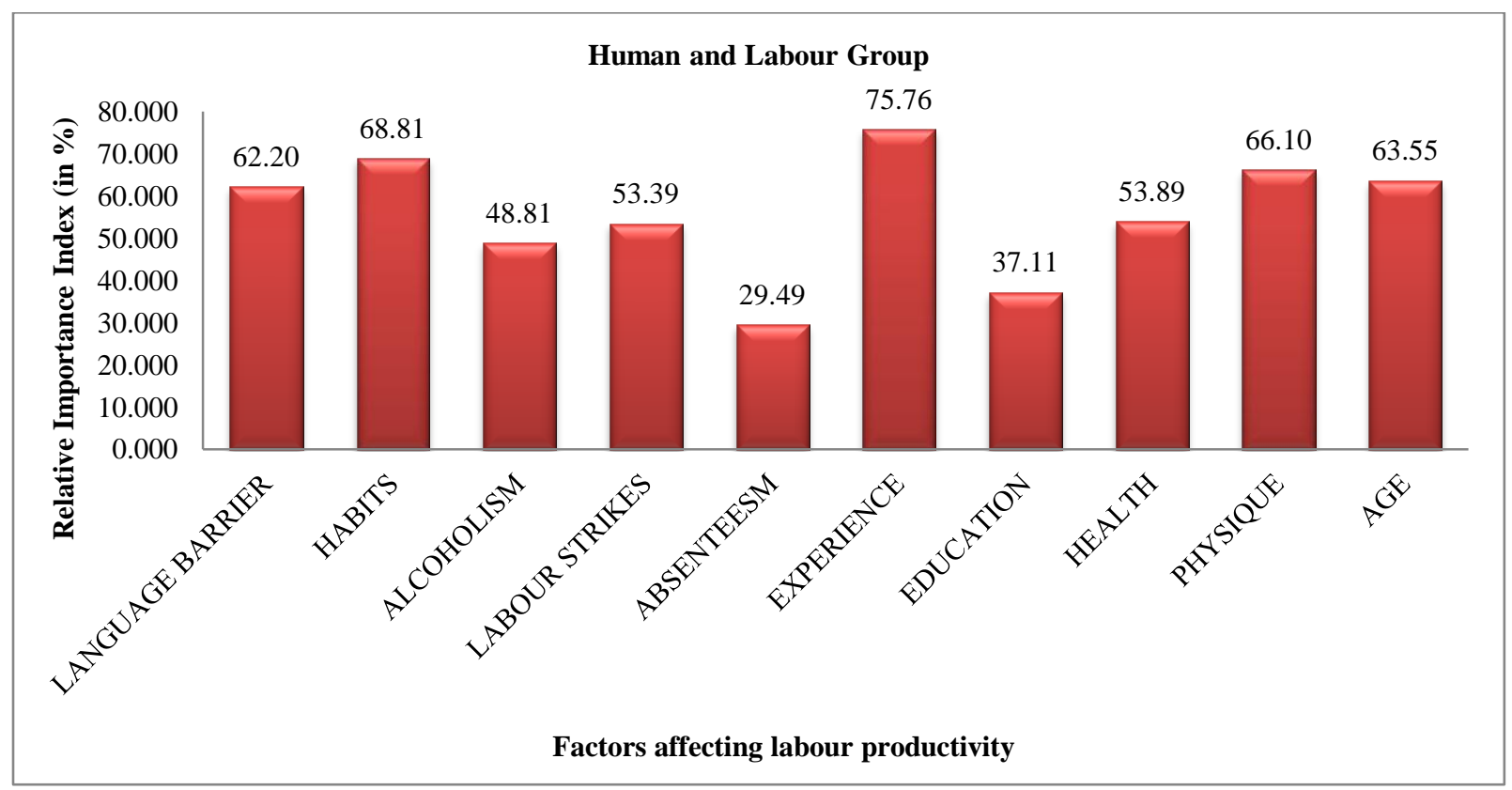

Figure 5 RII values of factors 


\subsection{Overall ranking}

This method emphasis on ranking the 27 factors according to their respective RII value. This will help us to find the top factors affecting the productivity in brickwork activity and proper measures can be taken to increase productivity. Table 2 below will show the overall ranking of 27 factors with their individual
RII. It can be observed that training is ranked 1 followed by quality required; experience, safety training, proper scheduling and over time have RII value as $76.441,76.102,75.763,74.746,74.407$ and 71.864 respectively.

Table 2 Overall ranking of the factors, according to the respective RII value

\begin{tabular}{|c|c|c|c|c|}
\hline SR. NO. & Factor affecting labour productivity & Group & RII & Rank \\
\hline 1 & Training & Management & 76.441 & 1 \\
\hline 2 & Quality Required & Management & 76.102 & 2 \\
\hline 3 & Experience & Human and Labour & 75.763 & 3 \\
\hline 4 & Safety Training & Management & 74.746 & 4 \\
\hline 5 & Proper Scheduling & Management & 74.407 & 5 \\
\hline 6 & Overtime & Management & 71.864 & 6 \\
\hline 7 & Types of Material & Project Specification & 71.186 & 7 \\
\hline 8 & Crew Size & Management & 70.678 & 8 \\
\hline 9 & Habits & Human and Labour & 68.814 & 9 \\
\hline 10 & Supervision & Management & 67.966 & 10 \\
\hline 11 & Equipment Availability & Management & 67.458 & 11 \\
\hline 12 & Physique & Human and Labour & 66.102 & 12 \\
\hline 13 & Design Rectification & Project Specification & 63.729 & 13 \\
\hline 14 & Age & Human and Labour & 63.559 & 14 \\
\hline 15 & Climate & Project Specification & 62.542 & 15 \\
\hline 16 & Language Barrier & Human and Labour & 62.203 & 16 \\
\hline 17 & Inspection Delay & Management & 59.661 & 17 \\
\hline 18 & Government Policies & Project Specification & 54.746 & 18 \\
\hline 19 & Health & Human and Labour & 53.898 & 19 \\
\hline 20 & Labour Strikes & Human and Labour & $\mathbf{5 3 . 3 9 0}$ & 20 \\
\hline 21 & Alcoholism & Human and Labour & 48.814 & 21 \\
\hline 22 & Material Delay & Management & 46.271 & 22 \\
\hline 23 & Bonus/Incentives & Management & 43.051 & 23 \\
\hline 24 & Overmaning & Management & 41.864 & 24 \\
\hline 25 & Site Environment & Management & 38.305 & 25 \\
\hline 26 & Education & Human and Labour & 37.119 & 26 \\
\hline 27 & Absenteeism & Human and Labour & 29.492 & 27 \\
\hline
\end{tabular}

\section{Discussion}

According to the results obtained from RII calculation, it can be stated "training" factors has the maximum RII value. This observation states that labour should be trained in brickwork operation to increase productivity. Similarly, "quality required" factors suggest us that if any site sets a target of the quality required of brickwork, then labours will commit a mistake in reaching that quality and also it will very time-consuming. "Experience" factors suggest us that the labour should have the experience of the brickwork so that it can be utilized in increasing productivity. Another factor "safety training" is responsible for providing safety training to the labour. The avoidance of accidents will increase productivity since the labour will know how to avoid accidents. "Proper scheduling" instruct us that no over-lapping of activities should be there in 
scheduling so that the completion of one work can be done and then the other can be started. In addition to the result, these factors "overtime" suggest that the labours should not be forced for working more. The efficiency of labour will be decreased if labours for more than assigned time. The result also showed that "management" is the most dominant group out of the three groups. The sub-factors in this group had maximum RII values which significantly affected the labour productivity. The group plays a major in completion of the work because all the decisionmaking power is with them. The result of previous researchers Abdul Kadir et al. [11] and Jarkas and Bitar [14] showed "management" group to be more responsible for affecting the labour productivity the most.

\section{Conclusion}

The current research aims to identify factors affecting the labour productivity of brickwork. Through the literature survey, 22 factors were identified and 5 factors were added, making 27 factors in all. These 27 factors were categorized into three main groups: (i) management, (ii) project specification and (iii) human and labour. A survey questionnaire was prepared and distributed among the site engineers of 130 under construction sites. Only 118 sites responded to the questionnaire. The obtained data analysis was done by using the Relative Importance Index method. Following factors were found in most significantly affecting the labour productivity of brickwork (i) training, (ii) quality required, (iii) experience, (iv) safety training, (v) proper scheduling and (vi) over time. It was also observed that management groups as the most responsible group for affecting labour productivity. In the overall ranking of the management group were found to be in the top 10. Following recommendations can be given on the obtained results.

- Proper training of the activity to be performed should be given to the labour so that the assigned work can be finished in stipulated time.

- Labours should be trained in safety precautions along with the training of activity to be performed.

- Proper scheduling of the activity plays a major role in labour productivity hence the overlapping of two activities should be avoided.

- Track of work completed should be supervised on the daily basis.

\section{Acknowledgment}

None.
Conflicts of interest

The authors have no conflicts of interest to declare.

\section{References}

[1] Soham M, Rajiv B. Critical factors affecting labour productivity in construction projects: case study of south Gujarat region of India. International Journal of Engineering and Advanced Technology. 2013; 2(4):583-91.

[2] Jergeas GF, McTague R. Construction productivity: an auditing and measuring tool. AACE International Transactions. 2002:CS91.

[3] Yi W, Chan AP. Critical review of labor productivity research in construction journals. Journal of Management in Engineering. 2013; 30(2):214-25.

[4] Arditi D. Construction productivity improvement. Journal of Construction Engineering and Management. 1985; 111(1):1-4.

[5] Peles CJ. Productivity analysis-a case study. In transaction of the american association of cost engineers, 31st Annual Meeting, Atlanta 1987.

[6] Handa VK, Abdalla O. Forecasting productivity by work sampling. Construction Management and Economics. 1989; 7(1):19-28.

[7] Allmon E, Haas CT, Borcherding JD, Goodrum PM. US construction labor productivity trends, 1970-1998. Journal of Construction Engineering and Management. 2000; 126(2):97-104.

[8] Arditi D, Mochtar K. Trends in productivity improvement in the US construction industry. Construction Management \& Economics. 2000; 18(1):15-27.

[9] Kenley R. More for less: a contractors guide to improving productivity in construction. Construction Management \& Economics. 2002.

[10] Tahir MA, Hashimhanif SZ, Hanif A. Factors affecting labor productivity in building projects of Pakistan. In proceedings of the seventh IIER international conference 2015.

[11] Abdul Kadir MR, Lee WP, Jaafar MS, Sapuan SM, Ali AA. Factors affecting construction labour productivity for Malaysian residential projects. Structural Survey. 2005; 23(1):42-54.

[12] Enshassi A, Mohamed S, Mustafa ZA, Mayer PE. Factors affecting labour productivity in building projects in the Gaza strip. Journal of Civil Engineering and Management. 2007; 13(4):245-54.

[13] Dai J, Goodrum PM, Maloney WF. Analysis of craft workers and foremens perceptions of the factors affecting construction labour productivity. Construction Management and Economics. 2007; 25(11):1139-52.

[14] Jarkas AM, Bitar CG. Factors affecting construction labor productivity in Kuwait. Journal of Construction Engineering and Management. 2011; 138(7):811-20.

[15] Hafez SM, Aziz RF, Morgan ES, Abdullah MM, Ahmed EK. Critical factors affecting construction labor productivity in Egypt. American Journal of Civil Engineering. 2014; 2(2):35-40. 
[16] Alaghbari W, Al-Sakkaf AA, Sultan B. Factors affecting construction labour productivity in Yemen. International Journal of Construction Management. 2019; 19(1):79-91.

[17] Rahman IA, Memon AH, Memon AQ, Shaikh MA, Siddiqui F. Factors affecting the labour productivity in construction projects of Pakistan. In MATEC Web of Conferences 2019.

[18] Gerges M, Ahiakwo O, Kapogiannis G, Saidani M, Saraireh D. Investigating and ranking labor productivity factors in the Egyptian construction industry. Journal of Architecture. 2011; 5(1):44-52.

[19] Porntepkasemsant P, Charoenpornpattana S. Factor affecting construction labor productivity in Thailand. In international conference on industrial engineering and operations management 2015 (pp. 1-6). IEEE.

[20] Olomolaiye PO, Wahab KA, Price AD. Problems influencing craftsmen's productivity in Nigeria. Building and Environment. 1987; 22(4):317-23.

[21] Zakeri M, Olomolaiye PO, Holt GD, Harris FC. A survey of constraints on Iranian construction operatives' productivity. Construction Management \& Economics. 1996; 14(5):417-26.

[22] Soekiman A, Pribadi KS, Soemardi BW, Wirahadikusumah RD. Factors relating to labor productivity affecting the project schedule performance in Indonesia. Procedia Engineering. 2011:865-73.

[23] Rad KG, Kim SY. Factors affecting construction labor productivity: Iran case study. Iranian Journal of Science and Technology, Transactions of Civil Engineering. 2018; 42(3).

[24] El-Gohary KM, Aziz RF. Factor's influencing construction labor productivity in Egypt. Journal of Management in Engineering. 2013; 30(1):1-9.

[25] Jarkas AM. Factors influencing labour productivity in Bahrain's construction industry. International Journal of Construction Management. 2015; 15(1):94-108.

[26] Hickson BG, Ellis LA. Factors affecting construction labour productivity in Trinidad and Tobago. The Journal of the Association of Professional Engineers of Trinidad and Tobago. 2014; 42(1):4-11.

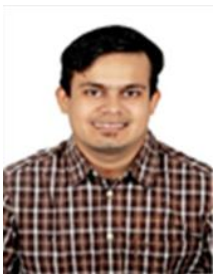

Mahesh S. Singh currently pursuing Master's in Construction Engineering and Management from Pillai HOC College of Engineering and Technology, Rasayani, University Mumbai. He did B.E. Civil from B. R. Harne College of Engineering and Technology, University of Mumbai.

Email: maheshsingh@mes.ac.in

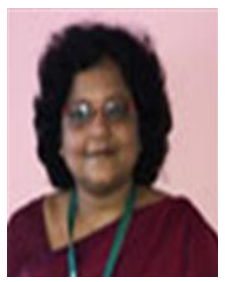

Dr. Tejaswini D. N., Professor, Pillai HOC College of Engineering and Technology, Rasayani. She did her $\mathrm{Ph} . \mathrm{D}$ in Environmental Engineering from IIT Bombay in 2015. M. Tech. in Environment Engineering from Visvesvaraya Technological University and B.E. Civil from Karnataka University. Her area of interest is Water Quality Management of Surface water, Solid Waste Management and Hazardous Waste Management.

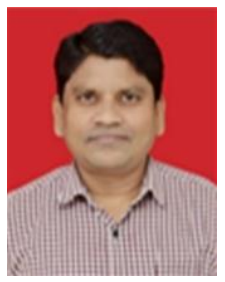

Raju Narwade, Assosicate Professor, Pillai HOC College of Engineering and Technology, Rasayani. He is currently pursuing Ph.D. in Water Resources Engineering from University of Mumbai. He did his M.E. Structural Engineering from University of Mumbai and B.E. Civil from Shri Guru Gobind Singhaji College of Engineering and Technology, Nanded. His area of interest is Structural Engineering, Hydrological Parameters Retrieval using Remote Sensing.

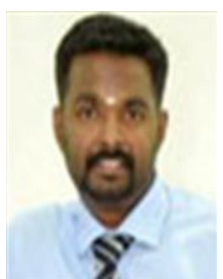

Karthik Nagarajan, Assosicate Professor, Pillai HOC College of Engineering and Technology, Rasayani. $\mathrm{He}$ is currently pursuing Ph.D. in Water Resources Engineering from University of Mumbai. He did his M.E. Structural Engineering from University of Mumbai and B.E. Civil from Pune University. His area of interest is Remote Sensing and GIS. 